\title{
PENGARUH INVESTASI ASET TIDAK BERWUJUD PADA KINERJA PERUSAHAAN
}

\author{
Mulyana $^{1)}$, Winanda Wahana Wahana Dalam ${ }^{2)}$ * \\ ${ }^{1}$ Akuntansi Manajerial, Politeknik Negeri Batam \\ email: mulyana.ana40@gmail.com \\ ${ }^{2}$ Akuntansi Manajerial, Politeknik Negeri Batam \\ email: winanda@polibatam.ac.id
}

\begin{abstract}
The importance of recording the company's investment in intangible assets needs to be reported in the financial statements for the benefits in the future. Intangible assets are one of the long-term investments made by the company now and can provide future profits in the company's market value. This study aims to re-raise the same topic more deeply about the effect of intangible asset investment on company performance. This research is a quantitative study by testing the hypothesis. The conclusion from the test results in research is that the higher a company is in investing in intangible assets, the higher the performance of a company.
\end{abstract}

Keywords: Intangible Assets, ROA, ROE, Tobin's Q, Company Size, Leverage

\begin{abstract}
ABSTRAK
pencatatan investasi perusahaan terhadap aset tidak berwujud perlu di laporkan dalam laporan keuangan untuk keuntungan yang dapat dirasakan perusahaan di masa depan. Aset tidak berwujud merupakan salah satu investasi jangka panjang yang dilakukan perusahaan sekarang dan dapat memberikan keuntungan di masa depan pada nilai pasar perusahaan. Penelitian ini bertujuan untuk kembali mengangkat topik yang sama lebih mendalam mengenai pengaruh investasi aset tidak berwujud terhadap kinerja perusahaan. Penelitian ini merupakan penelitian kuantitatif dengan melakukan pengujian terhadap hipotesisnya. Kesimpulan dari hasil pengujian dalam penelitian adalah semakin tinggi sebuah perusahaan dalam menginvestasikan aset tidak berwujud maka semakin tinggi kinerja suatu perusahaan.
\end{abstract}

Kata Kunci: Asset Tidak Berwujud, ROA, ROE, Tobin's Q, Ukuran Perusahaan, Leverage 


\section{PENDAHULAN}

Perusahaan dituntut untuk melakukan inovasi produk agar mampu bertahan dan berkompetisi seiring dengan pertumbuhan ekonomi (Kurniasari, 2015). Perusahaan diharapkan memanfaatkan teknologi baru untuk melakukan inovasi produk agar dapat mempertahankan keunggulan kompetitif yang dimiliki. Hal ini disebut the knowledge-based economy atau konsep perekonomian berbasis pengetahuan yaitu penekanan terhadap peran ilmu pengetahuan dan teknologi (IPTEK) dalam pertumbuhan ekonomi (OECD, 2013).

Perusahaan diharapkan menghasilkan produk yang inovatif dengan menerapkan perekonomian berbasis pengetahuan dengan optimal. Oleh karena itu, pentingnya investasi terhadap aset tidak berwujud dalam perusahaan perlu dilakukan (Soraya, 2013).

Nilai dari aset tidak berwujud dapat dilihat pada laporan keuangan perusahaan. Nilai dari sebuah perusahaan saat ini akan menggambarkan keuntungan yang diharapkan oleh perusahaan di masa depan (Horne, 2009). Pentingnya pencatatan terhadap investasi perusahaan terhadap aset tidak berwujud perlu di laporkan dalam laporan keuangan untuk keuntungan yang dapat dirasakan perusahaan di masa depan. Aset tidak berwujud merupakan salah satu investasi jangka panjang yang dilakukan perusahaan sekarang dan dapat memberikan keuntungan di masa depan pada nilai pasar perusahaan. Berinvestasi terhadap aset tidak berwujud dapat meningkatkan nilai pasar perusahaan (Mishara \& Jhunjhunwala, 2009).

Semakin tinggi investasi dalam aset tidak berwujud semakin rendah hutang yang dimiliki perusahaan menandakan semakin baik kinerja yang dilakukan perusahaan (Gamayuni, 2015). Pentingnya berinvestasi aset tidak berwujud dalam meningkatkan kinerja perusahaan (Bhatia \& Aggarwal, 2018). Kinerja suatu perusahaan yaitu hasil proses bisnis perusahaan atas pengorbanan berbagai macam sumber daya perusahaan, dan ketika kinerja meningkat dilihat dari proses kegiatan yang dilakukan perusahaan untuk menghasilkan keuntungan yang sebesar-besarnya (Moerdiyanto, 2010).

Perusahaan berusaha meningkatkan kinerja perusahaan dengan memanfaatkan kemajuan IPTEK agar dapat mencapai tujuan perusahaan yaitu memaksimalkan kekayaan. Penilaian terhadap kinerja pada perusahaan bertujuan untuk menentukan kemampuan efektivitas operasi perusahaan selama periode tertentu serta mengevaluasi hasil pekerjaan dari manajemen perusahaan.

Penilaian kinerja perusahaan dapat diukur melalui laporan keuangan perusahaan atas pencapaian laba pertahun dan penggunaan aktiva dalam perusahaan. Pecapaian laba pertahun yang dilakukan perusahaan untuk dapat mengukur bagaimana Kemampuan perusahaan memperoleh laba dalam menggunakan asetyang dimilki perusahaan yang dikenal istilah ROA. Kemampuan perusahaan memperoleh laba untuk mengukur modal yang dimilki perusahaan yang dikenal istilah ROE. Penilain lain yang dilakukan untuk mengukur kinerja perusahaan adalah Tobins'Q untuk mengukur kemampuan perusahaan dalam mengelola aktiva dalam pertumbuhan perusahaan.

Hasil dari penilaian kinerja perusahaan menjadi salah satu tolak ukur untuk pengambilan keputusan perusahaan sekarang untuk masa depan dari perusahaan. Investasi terhadap aset tidak berwujud merupakan salah satu keputusan sekarang untuk masa depan dalam perusahaan karena aset tidak berwujud merupakan investasi jangka panjang yang dirasakan di masa yang akan datang. Kinerja perusahaan yang baik akan meningkatan nilai dari perusahaan. Penelitian ini berusaha untuk memasukkan secara mendalam komponen aset tidak berwujud dan 
mengevaluasi pengaruh terhadap kinerja perusahaan.

Penelitian yang dilakukan di malaysia mengenai aset tidak berwujud menemukan bahwa aset tidak berwujud menjadi penentu penilaian di pasar Malaysia (Salamudin, 2010). Penelitian lain di malaysia yang dilakukan Haji \& Ghazali (2018) penelitian tersebut menyimpulkan adanya hubungan positif dan pengaruh aset tidak berwujud terhadap kinerja perusahaan.

Penelitian lain yang dilakukan oleh Bhatia \& Anggarwal (2018) mengenai pengaruh investasi aset tidak berwujud terhadap kinerja perusahaan. Menemukan bahwa ivestasi terhadap aset tidak berwujud memiliki pengaruh positif terhadap kinerja perusahaan yang berada di India. Penelitian yang dilakukan oleh Boapeah, Wang, Tunyi, Machokoto \& Zhang (2019) juga memperkuat hasil penelitian sebelumnya yang menemukan hubungan positif investasi aset tidak berwujud terhadap nilai saham di pasar asing.

Berbeda dengan penelitian sebelumnya bahwa ada nilai positif antara aset tidak berwujud pada kinerja suatu perusahaan. Penelitian yang dilakukan oleh Ruiwen \& Honghui (2010) menemukan pengaruh negatif antara aset tidak berwujud pada kinerja perusahaan. Hubungan antara aset tidak berwujud pada kinerja masih belum konsisten di luar negeri dan beberapa peneliti Indonesia juga meneliti dengan topik yang sama untuk menggeneralisasikan hasil.

Penelitian Indonesia juga menemukan hasil positif antara aset tidak berwujud terhadap kinerja perusahaan (Trisnajuna \& Sisdyani, 2015: Dewi \& Badjra, 2017). Peneliti Indonesia juga menemukan pengaruh negatif aset tidak berwujud pada kinerja perusahaan (Widiantoro, 2012). Beberapa penelitian yang telah dilakukan di luar negeri maupun dalam negeri mengenai peran aset tidak berwujud dan kewajiban tidak berwujud terhadap kinerja masih belum konsisten terhadap hasilnya.

Penelitian ini bertujuan untuk kembali mengangkat topik yang sama lebih mendalam mengenai pengaruh investasi aset tidak berwujud terhadap kinerja perusahaan. Penelitian ini mengacu pada penelitian Bhatia \& Anggarwal (2018) mengenai dampak investasi asset takberwujud pada kinerja perusahaan di india

penelitian ini menggunakan perusahaan yang terdaftar di IDX yaitu manufaktur sektor barang konsumsi di indonesia periode tahun 2014-2018, dikarenakan . Berdasarkan latar belakang yang telah diuraikan di atas, maka judul penelitian ini adalah "Pengaruh investasi aset tidak berwujud terhadap kinerja perusahaan."

\section{KAJIAN LITERATUR}

\section{The Knowledge Based Economy}

Menurut OECD (2013) The knowledge based economy adalah perekonomiaan berbasis pengetahuan yaitu suatu konsep yang menekankan pentingnya peran IPTEK terhadap pertumbuhan ekonomi. IPTEK yang dimiliki perusahaan dimanfaatkan dengan baik perusahaan sebagai keunggulan yang dimiliki terhadap inovasi produk perusahaan. Inovasi produk yang telah dilakukan perusahaan menjadi kunci perusahaan bertahan dipasaran.

IPTEK merupakan keunggulan yang kompetititif yang dimiliki perusahaan dalam pengembangan produk yang dimiliki perusahaan. Investasi perusahaan dalam melakukan pengembangan produk tersebut perlulah dilakukan agar produk perusahaan menjadi lebih inovatif dan investasi yang dilakukan adalah investasi terhadap aset tidak berwujud.

\section{Resource Based View of the firm (RBV)}

Pandangan RBV Theory Wernelfelt (1984) menyatakan bahwa perusahaan akan semakin unggul dengan cara memanfaatkan dari aset yang penting yaitu aset berwujud dan tidak berwujud 
sehingga menghasilkan kinerja keuangan yang baik. Kinerja perusahaan merupakan tolak ukur keberhasilan suatu manajemen perusahaan dalam mengelola perusahaan agar tetap bertahan di pasaran.

Berdasarkan pendekatan RBV dapat disimpulkan bahwa terdapat pengaruh antara sumber daya yang dimiliki suatu perusahaan pada kinerja perusahaan sehingga dapat meningkatkan nilai suatu perusahaan. Aset tidak berwujud merupakan salah satu sumber daya perusahaan yang dapat mempengaruhi kinerja perusahaan. Pengelolahan dana perusahaan oleh manajemen perusahaan berhak mengambil keputusan perusahaan terutama keputusan untuk memaksimalkan keuntungan di masa depan perusahaan dengan memanfaatan sumber daya perusahaan salah satunya terhadap aset tidak berwujud.

\section{Penelitian Terdahulu}

Penelitian mengenai pengaruh investasi dalam aset tidak berwujud pada kinerja perusahaan di India (Bhatia \& Aggarwal, 2018). Penelitian ini menggunakan investasi pada aset tidak berwujud sebagai variabel independen dan kinerja perusahaan sebagai variabel dependen. Penelitian tersebut menggunakan sampel 346 perusahaan sektor publik, perbankan dan sektor keuangan dari PROWRESS dari tahun 2000-2001 hingga 2011-2012. Penelitian ini menghasilkan bahwa aset tidak berwujud berpengaruh positif pada kinerja perusahaan di India. Terdapat variabel kontrol sebagai faktor lain untuk mengukur kinerja perusahaan yaitu ukuran perusahaa, umur, leverage, modal, risiko, pangsa pasar, industri dan waktu.

Penelitian tentang peran aset dan kewajiban tidak berwujud pada kinerja perusahaan (Haji \& Ghazali, 2018). Penelitian tersebut menggunakan 300 perusahaan terbesar di Malaysia pada periode 2008 hingga 2013. Berdasarkan 300 perusahaan tersebut menemukan hasil pentingnya pencatatan aset tidak berwujud pada laporan keuangan. Variabel yang diuji dalam penelitian tersebut adalah aset dan kewajiban tidak berwujud sebagai variabel independen dan kinerja perusahaan sebagai variabel dependen. Penelitian ini menemukan adanya pengaruh positif antara aset tidak berwujud sekarang dan periode sebelumnya pada kinerja perusahaan, serta menemukan pengaruh negatif kewajiban tidak berwujud tahun ini dan periode sebelumnya pada kinerja perusahaan.

Penelitian tentang penilaian aset tidak berwujud yang dillakukan di Pasar modal Malaysia (Salamudin, 2010). Sampel pada penelitian tersebut adalah semua sektor industri di Bursa Malaysia kecuali untuk sektor Pertambangan, Investasi Real Estate, dan Warant pada periode 20002006. Menyimpulkan bahwa aset tidak berwujud menjadi penentu penilaian di pasar Malaysia. Variabel independennya adalah aset tidak berwujud dan variabel dependen yaitu Nilai Perusahaan.

Studi membandingkan investasi aset tidak berwujud yang dilakukan perusahaan di Mesir dan Afrika selatan (Chen, 2018). Menyimpulkan bahwa Afrika selatan lebih konsisten terhadap aset tidak berwujud dibandingkan dengan negara Mesir. Afrika Selatan lebih banyak berinvestasi aset tidak berwujud terhadap R\&D sedangkan Mesir lebih banyak terhadap ekuitas merek dibandingkan dengan R\&D.

Penelitian mengenai pengaruh aset tidak berwujud pada kinerja perusahaan (Ruiwen \& Honghui, 2010). Variabel independen penelitian tersebut Aset tidak berwujud serta kinerja perusahaan merupakan dependen variabel. Sampel yang digunakan 34 perusahaan layanan sosial di sektor jasa. Kesimpulan penelitian tersebut adalah aset tidak berwujud berpengaruh negatif pada kinerja perusahaan.

Pengukuran pengaruh investasi aset tidak berwujud terhadap kesehatan keuangan perusahaan dan masalah keagenan (Widiantoro, 2012). Penelitian tersebut menyimpulkan bahwa investasi aset tidak 
berwujud tidak ada hubungan dengan kinerja perusahaan. Penelitian tersebut dilakukan di Indonesia dengan sampel 30 perusahaan yang terdaftar dalam BEI. Variabel independennya penelitian tersebut adalah aset tidak berwujud sedangkan variabel dependennya adalah kesehatan keuangan perusahaan dan keagenan.

\section{Pengembangan Hipotesis}

Kinerja perusahaan diukur melalui bagaimana perusahaan memperoleh laba dalam menggunakan dana yang dimiliki dengan ratio ROA, bagaimana perusahaan memperoleh laba dalam menggunakan modal perusahaan dengan ratio ROE. Pengukuran lain untuk mengukur kinerja perusahaan adalah bagaimana perusahaan dalam mengelola aktiva yang dimiliki dalam berinvestasi dengan Tobins'Q. Berdasarkan pernyataan tersebut sehingga hipotesis yang diajukan dari penelitian ini adalah:

H1: Aset tidak berwujud memiliki pengaruh signifikan terhadap ROA

$\mathrm{H} 2$ : Aset tidak berwujud memiliki pengaruh signifikan terhadap ROE

H3: Aset tidak berwujud memiliki pengaruh signifikan terhadap TOBIN'S Q.

Berikut adalah model penelitian dari hipotesis tersebut:

Gambar 1

Model Penelitian

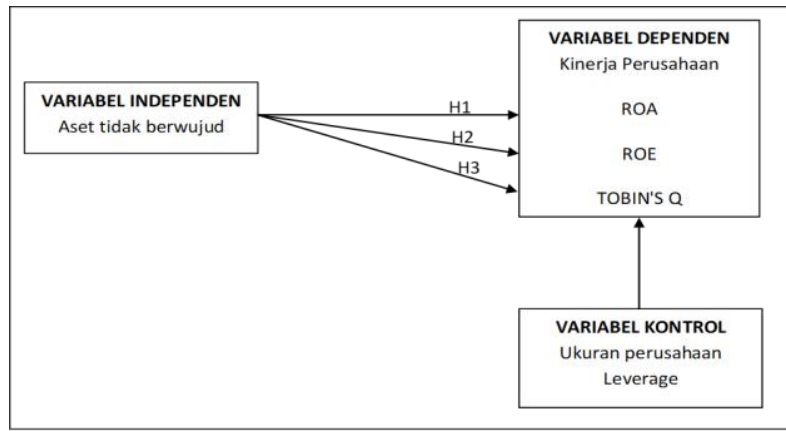

Sumber: Diolah Sendiri

\section{METODE PENELITIAN}

\section{Variabel Independen}

Variable Independen dalam penelitian ini adalah aset tidak berwujud, dalam PSAK
No.19 (Revisi 2010) Aset tidak berwujud adalah aset non moneter yang dapat diidentifikasi tanpa wujud fisik. Rumus yang dikembangkan oleh Karl-Erik Sveiby (1997) dengan metode intangible aset monitor method dengan selisih nilai pasar dan buku entitas, yang telah digunakan oleh Salamudin (2010), Haji \& Ghazali (2018), dan Bhatia \& Aggrawal (2018), sehingga di peroleh rumus sebagai berikut:

\begin{tabular}{|c|}
\hline Nilai Pasar= Jumlah Saham X Harga Saham \\
Nilai Buku Entitas = Total Aset - Total Kewajiban \\
\hline Sumber: Sveiby (1997) \\
Aset tidak berwujud = Nilai pasar - buku \\
entitas
\end{tabular}

Sumber: Sveiby (1997)

\section{Variable Dependen}

a) Return On Assets

ROA digunakan oleh manajemen untuk mengevaluasi kinerja suatu perusahaan. ROA di penelitian ini diproksikan dengan laba bersih per total aktiva perusahaan, sehingga dirumus sebagai berikut:

ROA $=\frac{\text { Laba Bersih }}{\text { Total Aktiva }} \times 100 \%$

Sumber: Munawir (2010)

b) Tobin's Q

Tobin's Q mendeskripsikan peluang investasi perusahaan, dengan proksi nilai Tobin's $Q$ diperoleh dari total outstanding share dan total utang dibandingkan aktiva tetap perusahaan. Sehingga didapatkan rumus sebagai berikut:

$$
\frac{\text { MVS }+D}{\text { Total Asset }}
$$

MVS = Market value of all outstanding shares pada tahun $\mathrm{t}$

$\mathrm{D} \quad=$ Total utang pada tahun $\mathrm{t}$ 


\section{Variable Control}

a) Ukuran Perusahaan

Ukuran perusahaan adalah besar kecilnya perusahaan yang dapat diukur dengan total aktiva atau besar harta perusahaan dengan menggunakan perhitungan nilai logaritma dari total aktiva (Hartono, 2008). Ukuran perusahaan di penelitian ini diproksikan dengan total seluruh aset yang dimiliki perusahaan, sehingga didapatkan rumus sebagai berikut:

$$
\begin{aligned}
& \text { Size }=\text { Ln Total Aset } \\
& \text { Sumber: Munawir (2010) }
\end{aligned}
$$

b) Leverage

Leverage di penelitian ini diproksikan dengan total hutang per total aset yang dimiliki perusahaan, sehingga didapatkan rumus sebagai berikut:

Leverage $=\frac{\text { Total Hutang }}{\text { Total Aset }} \times 100 \%$

Sumber: Kieso, Weygandt \& Warfield (2008)

\section{Uji T-Statistik}

Uji ini digunakan untuk menguji bagaimana pengaruh variabel independen terhadap variabel dependen secara parsial. Jika nilai signifikansi $<0,05$, maka terdapat pengaruh yang signifikan antara variabel independen terhadap variabel dependen, dan sebaliknya.

\section{Uji F-Statistik}

Uji signifikan simultan atau uji statistik $\mathrm{F}$ digunakan untuk mengetahui apakah variabel independen atau variabel bebas secara bersama-sama mempunyai pengaruh terhadap variabel dependen atau variabel terikat. apabila Fhitung < Ftabel atau sig. $>\alpha(\alpha=0,05)$, maka variabel independen tidak mampu menjelaskan variabel dependen secara bersama-sama ataupun sebaliknya (Ghozali, 2016).

\section{Regresi Sederhana}

Regresi dapat dihitung dengan rumus berikut:
ROA/ROE/TOBINS'Q $=\alpha t+\beta 1$ IAit + $\beta 2$ SIZEit $+\beta 3$ LEVit $+\varepsilon$ it

Keterangan:

$\alpha=$ Nilai konstanta

$\beta \quad=$ Koefisien Regresi

IA = Intangible Assets (Aset tidak berwujud)

SIZE = Ukuran perusahaan

LEV = Leverage

cit $=$ Error

Pengambilan dasar keputusan pada analisis regresi dapat dilihat dari nilai signifikansi dari uji t, yaitu apabila nilai siginifikansi >0,05 maka tidak ada pengaruh dari variabel independen terhadap variabel dependen. Sebaliknya, apabila nilai signifikansi $<0,05$ maka terdapat pengaruh dari variabel independen terhadap variabel dependen.

\section{Koefisien Determinasi}

Koefisien Determinasi $\left(\mathrm{R}_{2}\right)$ pada intinya mengukur seberapa jauh model dalam menerangkan variasi variabel dependen. Nilai koefisien determinasi adalah antara nol dan satu (Ghozali, 2016).

\section{HASIL DAN PEMBAHASAN}

Total sampel keseluruhan selama tahun 2014-2018 yang memenuhi kriteria yang telah ditetapkan sebesar 145 data.

\section{Statistik Deskriptif} ini adalah

Statistik deskriptif pada penelitian

Tabel 4.2

Statistik Deskriptif

\begin{tabular}{|l|l|r|r|r|r|}
\hline \multicolumn{6}{|c|}{ Descriptive Statistic } \\
\hline & N & Minimum & Maximum & Mean & Std. Deviation \\
\hline IA & 145 & 6.77 & 9.84 & 8.16 & 0.75 \\
\hline ROA & 145 & -17.61 & 35.29 & 6.15 & 7.99 \\
\hline ROE & 145 & -37.98 & 74.2 & 9.43 & 12.86 \\
\hline TQ & 145 & 0.51 & 2.5 & 1.82 & 0.32 \\
\hline SZ & 145 & 11.48 & 18.38 & 14.63 & 1.59 \\
\hline LEV & 145 & 11.83 & 83.87 & 41.23 & 16.78 \\
\hline
\end{tabular}

Sumber: Hasil Olahan SPSS 20

Rata-rata perusahaan dapat menghasilkan laba sebesar 6,15 dari total aset yang dimiliki. Laba bersih tertinggi yaitu H.M. 
Sampoerna Tbk pada tahun 2014 sebesar 35,29 dari total aset dalam memperoleh laba bersih. Laba bersih terendah yaitu Martina Berto Tbk pada tahun 2018 sebesar $-17,61$ dari total aset, dan nilai ketimpangan antara nilai tertinggi dan terendah sebesar 7,99.

Rata-rata perusahaan mendapatkan laba bersih sebesar 9,43 dari total ekuitas. Laba bersih tertinggi yaitu H.M. Sampoerna Tbk pada tahun 2014 sebesar 74,20 dari total ekuitas untuk mendapatkan laba bersi, laba bersih terendah yaitu Martina Berto Tbk pada tahun 2018 sebesar $-37,98$ dari total ekuitas, dan nilai ketimpangan antara nilai tertinggi dan nilai terendah sebesar 12,86. Proksi ketiga adalah Tobin's Q yang diukur menggunakan penjumlahan market value equity dengan total liabilitas per total aset. Rata-rata perusahaan yang mengetahui nilai pasar sebesar 1,82 . Nilai pasar tertinggi dalam mencerminkan keuntungan perusahaan yaitu Phapros Tbk pada tahun 2018 sebesar 2,50. Nilai pasar terendah yaitu Garudafood Putra Putri Jaya Tbk pada tahun 2018 sebesar 0,51. Nilai ketimpangan antara nilai tertinggi dan nilai terendah sebesar 0,32 .

\section{Hasil Pengujian Asumsi Klasik}

Uji Normalitas

Hasil uji normalitas adalah sebagai berikut Tabel 4.3

Hasil Uji Normalitas

\begin{tabular}{|c|l|l|l|l|}
\hline \multirow{2}{*}{ Keterangan } & \multicolumn{3}{|c|}{ Nilai Sig K-S } & \multirow{2}{*}{ Kesimpulan } \\
\cline { 2 - 4 } & ROA & ROE & TQ & Data \\
\hline $\begin{array}{c}\text { Asymp. Sig. } \\
\text { (2tailed) }\end{array}$ & 0.114 & 0.143 & 0.0074 & $\begin{array}{c}\text { Terdistribusi } \\
\text { normal }\end{array}$ \\
\hline
\end{tabular}

Sumber: Hasil Olahan SPSS 20

Hasil yang diperoleh memiliki nilai yang lebih besar dari 0,05 maka dapat disimpulkan bahwa data penelitian ini terdistribusi normal.

Uji Multikolinearitas

Hasil pengujian multikolinearitas dapat dilihat pada table:
Tabel 4.4

Hasil Uji Multikolinieritas

\begin{tabular}{|c|r|r|r|l|}
\hline Variable & \multicolumn{3}{|c|}{ Nilai Sig } & \multirow{2}{*}{ Kesimpulan } \\
\cline { 2 - 4 } $\begin{array}{c}\text { Independen } \\
\text { dan Kontrol }\end{array}$ & ROA & ROE & TQ & \\
\hline IA & 5.703 & 5.703 & 5.703 & Tidak terjadi Multikolineritas \\
\hline SZ & 5.73 & 5.73 & 5.73 & Tidak terjadi Multikolineritas \\
\hline LEV & 1.029 & 1.029 & 1.029 & Tidak terjadi Multikolineritas \\
\hline
\end{tabular}

Sumber: Hasil Olahan SPSS 20

Penarikan kesimpulan dilakukan dengan melihat nilai VIF yang lebih kecil dari 10,00 maka tidak terjadi multikolinearitas. Semua variabel yang diuji telah memenuhi kriteria yang telah ditetapkan, maka dapat dinyatakan bahwa semua variabel tidak terdapat adanya multikolinearitas

Uji Heteroskedastisitas

Hasil pengujian dapat dilihat pada tabel berikut:

Tabel 4.5

Hasil Uji Heterokedastisitas

\begin{tabular}{|c|c|c|c|c|}
\hline \multirow{2}{*}{$\begin{array}{c}\text { Variable } \\
\text { Independen } \\
\text { dan Kontrol }\end{array}$} & \multicolumn{3}{|c|}{ Nilai Sig } & \multirow{2}{*}{ Kesimpulan } \\
\cline { 2 - 4 } & ROA & ROE & TQ & \\
\hline IA & 0.202 & 0.629 & 0.213 & Tidak terjadi heterokedastisitas \\
\hline SZ & 0.092 & 0.393 & 0.647 & Tidak terjadi heterokedastisitas \\
\hline LEV & 0.536 & 0.207 & 0.178 & Tidak terjadi heterokedastisitas \\
\hline
\end{tabular}

Sumber: Hasil Olahan SPSS 20

Hasil dari semua variabel yang telah diuji memiliki nilai lebih besar dari 0,05 maka dapat disimpulkan bahwa penelitian ini tidak mengalami masalah heteroskedastisitas.

\section{Hasil Pengujian Hipotesis Pertama}

Tabel 4.6

Hasil Pengujian Hipotesis 1

\begin{tabular}{|l|r|r|l|}
\hline Variable & Koefisien Regresi & T-hitung & Sig \\
\hline Constant & -26.818 & -4.807 & 0.000 \\
\hline IA & 3.554 & 2.310 & 0.022 \\
\hline SZ & 0.912 & 1.244 & 0.216 \\
\hline LEV & -0.230 & -7.808 & 0.000 \\
\hline R-Square $=0.477$ \\
\hline \multicolumn{4}{|l}{ Fhitung=42.946 } \\
\hline \multicolumn{4}{|l}{ Signifikan F =0.000 } \\
\hline
\end{tabular}

Sumber: Hasil Olahan SPSS 20

Persamaan regresi di atas menunjukkan pengaruh secara bersama-sama antara variabel independen dan variabel kontrol 
pada variabel dependen dengan nilai signifikan 0,000. Artinya bahwa IA, SZ, dan LEV berpengaruh secara bersamasama terhadap ROA

Berdasarkan tabel 4.6, $\mathrm{H}_{1}$ variabel Aset tidak berwujud diperoleh thitung sebesar 2,310 dan nilai signifikansi $t$ sebesar 0,022. Nilai signifikansi tersebut dinyatakan lebih kecil dari 0,05 , sehingga dapat disimpulkan bahwa hipotesis $\mathrm{H}_{1}$ terdukung.

\section{Hasil Pengujian Hipotesis kedua}

Hasil analisis dapat dilihat pada table:

Tabel 4.7

Hasil Pengujian Hipotesis kedua

\begin{tabular}{|l|r|r|l|}
\hline Variable & Koefisien Regresi & T-hitung & Sig \\
\hline Constant & -52.644 & -5.338 & 0.000 \\
\hline IA & 6.828 & 2.472 & 0.015 \\
\hline SZ & 1.067 & 0.812 & 0.418 \\
\hline LEV & -0.225 & -4.472 & 0.000 \\
\hline R-Square $=0.354$ & \\
\hline Fhitung=25.728 \\
\hline \multicolumn{4}{|r|}{ Signifikan F $=0.000$} \\
\hline
\end{tabular}

Sumber: Hasil Olahan SPSS 20

Persamaan regresi di atas menunjukkan pengaruh secara bersama-sama antara variabel independen dan variabel kontrol pada variabel dependen dengan nilai signifikan 0,000. Artinya bahwa IA, SZ, dan LEV berpengaruh secara bersamasama terhadap ROE.

Berdasarkan tabel 4.6, $\mathrm{H}_{2}$ variabel aset tidak berwujud diperoleh $t_{\text {hitung }}$ sebesar 2,472 dan nilai signifikansi $t$ sebesar 0,015. Nilai signifikansi tersebut dinyatakan lebih kecil dari 0,05 , sehingga dapat disimpulkan bahwa hipotesis $\mathrm{H}_{2}$ terdukung.

\section{Hasil Pengujian Hipotesis ketiga}

Tabel 4.8

Hasil Pengujian Hipotesis ketiga

\begin{tabular}{|l|r|r|l|}
\hline Variable & Koefisien Regresi & T-hitung & Sig \\
\hline Constant & 0.041 & 0.404 & 6.687 \\
\hline IA & 0.943 & 33.318 & 0.000 \\
\hline SZ & -0.407 & -30.240 & 0.000 \\
\hline LEV & 0.001 & 1.615 & 0.109 \\
\hline R-Square $=0.888$ \\
\hline Fhitung=374.252 \\
\hline \multicolumn{3}{|r|}{ Signifikan F $=0.000$} \\
\hline
\end{tabular}

Sumber: Hasil Olahan SPSS 20
Persamaan regresi di atas menunjukkan pengaruh secara bersama-sama antara variabel independen dan variabel kontrol pada variabel dependen dengan nilai signifikan 0,000. Artinya bahwa IA, SZ, dan LEV berpengaruh secara bersamasama terhadap Tobin's Q.

Berdasarkan tabel 4.6, $\mathrm{H}_{3}$ variabel aset tidak berwujud diperoleh thitung sebesar 33,318 dan nilai signifikansi $\mathrm{t}$ sebesar 0,000. Nilai signifikansi tersebut dinyatakan lebih kecil dari 0,05 , sehingga dapat disimpulkan bahwa hipotesis $\mathrm{H}_{3}$ terdukung.

\section{ANALISIS DATA}

\section{Investasi Aset tidak berwujud berpengaruh terhadap ROA}

Berdasarkan uji statistik, hasil pengujian $\mathrm{H}_{1}$ yang telah dijelaskan pada tabel 4.6 menunjukkan terdapat pengaruh yang signifikan antara investasi aset tidak berwujud terhadap kinerja perusahaan yang dilihat dari segi keuangan perusahaan diproksikan dengan ROA. Hal ini sesuai dengan pandangan Wernelfelt (1984) mengenai teori Resource Based View of the firm menyatakan bahwa perusahaan akan semakin unggul dengan cara memanfaatkan dari aset yang penting yaitu aset berwujud dan tidak berwujud sehingga menghasilkan kinerja keuangan yang baik.

Pemanfaatan aset dalam perusahaan dengan melakukan investasi terhadap aset tidak berwujud maka semakin tinggi kinerja keuangan dalam pengelolaan aset terhadap laba yang diperoleh yang dapat diprosksikan dengan nilai dari ROA. Kinerja keuangan perusahaan yang baik maka kinerja yang dimiliki perusahaan juga baik. Penelitian ini sesuai dengan penelitian yang telah dilakukan oleh Zhu \& Huang (2012), Gamayuni (2015), Trisnajuna \& Sisdyani (2015), Haji \& Ghazali (2018), Bhatia \& Anggarwal (2018) yang menyatakan bahwa terdapat pengaruh antara aset tidak berwujud terhadap kinerja perusahaan yang diukur dengan nilai ROA. 


\section{Investasi Aset tidak berwujud berpengaruh terhadap ROE}

Berdasarkan uji statistik, hasil pengujian $\mathrm{H}_{2}$ yang telah dijelaskan pada tabel 4.7 menunjukkan terdapat pengaruh yang signifikan antara investasi aset tidak berwujud terhadap kinerja perusahaan yang dilihat dari segi keuangan diproksikan dengan ROE. Hal ini sesuai dengan pandangan Wernelfelt (1984) mengenai teori Resource Based View of the firm menyatakan bahwa perusahaan akan semakin unggul dengan cara memanfaatkan dari aset aset berwujud dan tidak berwujud sehingga menghasilkan kinerja keuangan yang baik.

Pemanfaatan aset perusahaan dengan melakukan investasi terhadap aset tidak berwujud maka semakin tinggi kinerja keuangan dalam pengelolaan aset perusahaan yang dapat mempengaruhi modal yang dimiliki perusahaan terhadap laba yang dapat dilihat dari nilai dari ROE. penelitian yang telah dilakukan oleh Zhu \& Huang (2012), Widiantoro (2012), Aida \& Rahmawati (2015), Haji \& Ghazali (2018), Bhatia \& Aggarwal (2018) yang menyatakan bahwa terdapat pengaruh antara aset tidak berwujud terhadap kinerja perusahaan yang diukur dengan nilai ROE.

\section{Investasi Aset tidak berwujud berpengaruh terhadap TOBIN'S Q}

Berdasarkan uji statistik, hasil pengujian $\mathrm{H}_{3}$ yang telah dijelaskan pada tabel 4.8 menunjukkan terdapat pengaruh yang signifikan antara Investasi aset tidak berwujud terhadap kinerja perusahaan yang dilihat dari nilai pasar perusahaan yang diproksikan dengan Tobin's Q.

RBV adalah teori yang dipelajari dan dikembangkan untuk menganalisis keunggulan bersaing perusahaan sekarang dengan perusahaan lainnya yang menonjolkan pengetahuan atau perekonomian yang mengutamakan asetaset tidak berwujud yang dimiliki perusahaan (Aida \& Rahmawati, 2015). Pemanfaatan ilmu pengetahuan dalam mengutamakan investasi dalam bentuk aset tidak bewujud dapat meningkatkan persaingan perusahaan dengan perusahaan lain. Meningkatnya persaingan perusahaan dapat meningkatkan pertumbahan perusahan di pasar sehingga dapat meningkatkan nilai pasar perusahaan.

Menurut OECD (2001) Teori The knowledge based economy adalah perekonomian berbasis pengetahuan yaitu suatu konsep yang menekankan pentingnya peran IPTEK terhadap pertumbuhan ekonomi. IPTEK merupakan keunggulan yang kompetititif yang dimiliki perusahaan dalam pengembangan produk yang dimiliki perusahaan. Pengembangan produk yang dilakukan perusahaan dalam pemanfaatan IPTEK yang dimiliki dalam tranformasi produk yang dicatat dalam bentuk aset tidak berwujud berpengaruh pada nilai pasar. Nilai Pasar dalam perusahaan dapat diukur untuk menilai kinerja perusahaan menggunakan nilai dari Tobin's Q.

Semakin tinggi dalam pemanfaatan IPTEK dalam investasi perusahaan dalam bentuk aset tidak berwujud maka semakin tinggi nilai pasar perusahaan membuktikan semakin tinggi kinerja perusahaan. Penelitian ini sesuai dengan penelitian yang telah dilakukan oleh Widiantoro (2012), Gamayuni (2015), Bhatia \& Aggarwal (2018) yang menyatakan bahwa terdapat pengaruh antara aset tidak berwujud pada kinerja perusahaan yang diukur dengan nilai Tobin's Q.

\section{KESIMPULAN DAN SARAN}

Penelitian ini bertujuan memberikan bukti empiris dan mengetahui pengaruh aset tidak berwujud pada kinerja perusahaan manufaktur sektor industri barang konsumsi yang terdaftar di BEI pada periode 2014-2018. Kesimpulan dari hasil pengujian dalam penelitian adalah semakin tinggi sebuah perusahaan dalam menginvestasikan aset tidak berwujud maka semakin tinggi kinerja suatu perusahaan. Kinerja perusahaan dapat dilihat dari kinerja keuangan yang dimiliki 
suatu perusahaan dalam mengelola aset terhadap memperoleh laba dengan proksi nilai ROA dengan 2 dengan variabel kontrol yaitu leverage terdukung sedangkan ukuran perusahaan tidak terdukung.

Kinerja keuagan lain dalam melihat kinerja perusahaan yaitu dalam mengelola modal terhadap memperoleh laba dengan proksi ROE dengan 2 dengan variabel kontrol yaitu leverage terdukung sedangkan ukuran perusahaan tidak terdukung. Kinerja suatu perusahaan juga dapat dilihat dari nilai pasar suatu perusahaan dengan proksi Tobin's Q dengan 2 dengan variabel kontrol yaitu ukuran perusahaan terdukung sedangkan leverage tidak terdukung. Semakin tinggi kinerja keuangan dan nilai suatu perusahaan menandakan semakin baik kinerja perusahaan.

\section{Saran}

Saran untuk penelitian selanjutnya adalah:

1. Penelitian selanjutnya dapat memperluas lokasi dan objek penelitian, hanya sebatas sektor manufaktur namun menambah sampel pada seluruh sektor perusahaan yang terdaftar di idx.

2. Penelitian selanjutnya tidak hanya berfikus terhadap aset tidak berwujud saja dapat menambahkan reseach and develompent sebagai contoh dari aset tidak berwujud.

3. Penelitian selanjutnya dapat menambah proksi yang digunakan pada kinerja perusahaan.

\section{DAFTAR PUSTAKA}

Aida, R. N., \& Rahmawati, E. (2015). Pengaruh Modal Intelektual dan Pengungkapannya Terhadap Nilai Perusahaan. Jurnal Akuntansi \& Investasi.

Bhatia, A., \& Aggarwal, K. (2018). Impact of Investment in Intagible Assets on Corporate Permormance in India.
International Journal of Law and Management, 60(5), 1058-1073.

Chen. (2005). An Empirical Investigation of the Relationship between Intellectual Capital and Firm 's Market Value and Financial Permormnce. Journal of Intellectual Capital.

Gamayuni, R. R. (2015). The Effect Of Intangible Asset, Financial Performance And Financial Policies On The Firm Value. International Journal Scientific \& Tecnology Reseach, 2277-8618.

Haji, A. A., \& Ghazali, n. A. (2018). The role of intangible assets and liabilities in firm performance. Accounting Reseach.

Horne, J. (2009). Prinsip-prinsip Manajemen Keuangan. Jakarta: Salemba Empat.

Kasmir. (2015). Analisis Laporan Keuangan. Jakarta: PT Raja Grafindo Persaja.

Kieso, D., Weygandt, J., \& Warfield, T. (2008). Intermadiate Accounting. America: Wiley.

Mishara, R. K., \& Jhunjhunwala, S. (2009). Valuation of Intangibles. Study Sponsored by ICAI.

Moerdiyanto. (2010). Tingkat Pendidikan Manajer dan Kinerja Perusahaan Go Public.

Munawir. (2010). Analisis Laporan Keuangan. Yogyakarta: Liberty.

Salamudin, N. (2010). Intangible Assets Valuation in the Malaysia Capital Market. Journal Intelectual Capital, 391-405. 
Salvonte, D. (2005). In Ekonomi Manajerial. Jakarta: Salemba.

Soraya, L. (2013). Pengaruh Nilai Aset Tidak Berwujud dan penelitian dan pengembangan terhadap Nilai Pasar Perusahaan. Universitas Dipenogoro Semarang.

Suad, H. (1997). Manajemen Keuangan teori dan Penerapan (Keputusan Jangka Panjang). Yogyakarta: BPFE.

Trisnajuna, M., \& Sisdyani, E. A. (2015). Pengaruh Aset Tidak Berwujud dan Biaya Penelitian dan Pengembangan terhadap Nilai Pasar dan Kinerja Keuangan Perusahaan. E-Jurnal Akuntansi Universitas Udayana, 888-915.

Widiantoro, D. M. (2012). Measuring the Impact of Intangible Asset Investment toward Companies Financial Health and Agency Problem. Kristiansand School of Management.

Zhu, Z., \& Huang, F. (2012). The Effect of R\&D Investment on Firms' Financial Performance: Evidence from the Chinese Listed IT Firms. Scientific Search, 915-919. 